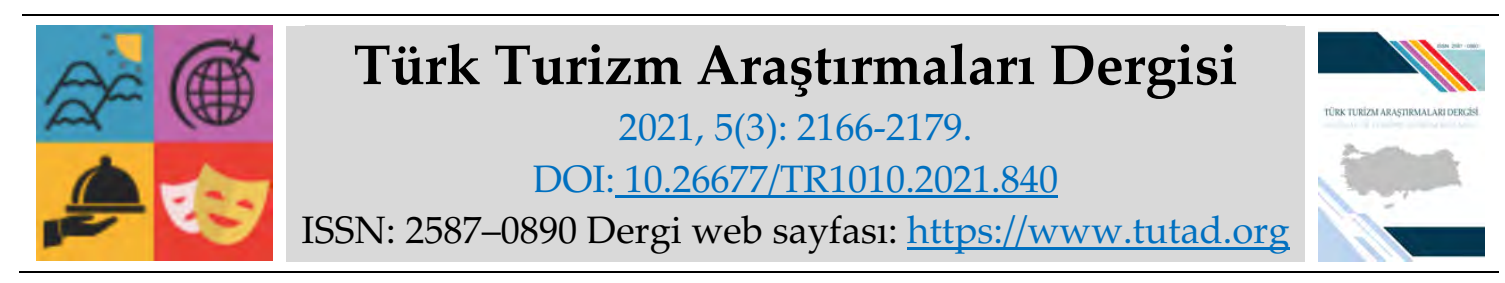

ARASTTIRMA MAKALESI

\title{
Turist Rehberlerinin Kültürel Miras Aktarımında Hikâye Anlatıcılığının Rolü
}

Büşra KAYA, Doktora Öğrencisi, Ankara Hacı Bayram Veli Üniversitesi, Lisansüstü Eğitim Enstitüsü, Ankara, e-posta: busra.kaya650@hbv.edu.tr ORCID: https://orcid.org/0000-0002-6133-7518

Prof. Dr. Kurban ÜNLÜÖNEN, Ankara Hacı Bayram Veli Üniversitesi, Turizm Fakültesi, Ankara, e-posta: kurban.unluonen@hbv.edu.tr ORCID: https://orcid.org/0000-0002-4191-9019

Öz

Çalışma ile turist rehberlerinin kültürel miras aktarımı esnasında hikâye anlatımının rolünü incelemek amaçlanmıştır. Sürdürülebilir değerler, oldukça önem kazanmış durumdadır. Bu bağlamda, kültürel mirasın da sürdürülebilir olması oldukça önem taşımaktadır. Turist rehberleri bu açıdan ele alındığında, kültürel mirası gelecek nesillere aktaran anlatıcılardır. Bu nedenle, destinasyonlara ait hikâyelerin, turistler üzerinde nasıl bir rol oynadığını belirlemek adına, doğrudan bu hikâyeleri anlatarak tepkileri gözlemleme fırsatı olan turist rehberleri ile görüşülmüştür. Çalışma nitel araştırma yöntemlerinden vaka çalışması desenine dayanarak hazırlanmıştır. Veriler, aktif olarak turist rehberi olarak görev yapan 16 kişiden, yarı yapılandırılmış soru formu aracılığı ile toplanmıştır. Elde edilen veriler için içerik analizi kullanılmıştır. Çalışmanın bulgularına göre; hikâye anlatımı, kültürel mirası aktarma sürecini çok daha ilgi çekici, akılda kalıcı, eğlenceli ve bilgilendirici kılmaktadır. Sonuçlar ışığında bir model geliştirilmiştir. Model üzerinde, hikâye anlatımının ise hem turist rehberleri (anlatıcı) hem de turistler (dinleyici) açısından rolleri verilmiştir. Hikâye anlatımı sonrası çıktılar ise turistler, turist rehberleri ve kültürel miras bağlamında incelenmektedir.

Anahtar Kelimeler: Hikâye Anlatıcılığı, Turist Rehberi, Kültürel Miras.

Makale Gönderme Tarihi: 29.06.2021

Makale Kabul Tarihi: 04.09.2021

\section{Önerilen Atıf:}

Kaya, B. ve Ünlüönen, K. (2021). Turist Rehberlerinin Kültürel Miras Aktarımında Hikâye Anlatıcılığının Rolü, Türk Turizm Araştırmaları Dergisi, 5(3): 2166-2179.

(c) 2021 Türk Turizm Araştırmaları Dergisi. 


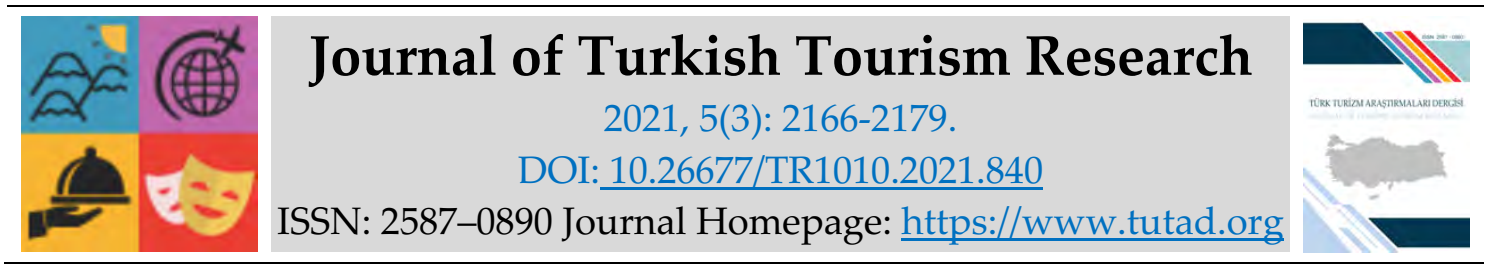

\title{
RESEARCH PAPER
}

\section{The Role of Storytelling on Cultural Heritage Transfer of Tourist Guides}

Büşra KAYA, Ph.D. Student, Ankara Hacı Bayram Veli University, Graduate School of Education, Ankara, e-mail: busra.kaya650@hbv.edu.tr ORCID: https://orcid.org/0000-0002-6133-7518

Prof. Dr. Kurban ÜNLÜÖNEN, Ankara Hacı Bayram Veli University, Faculty of Tourism, Ankara, e-mail: kurban.unluonen@hbv.edu.tr ORCID: https://orcid.org/0000-0002-4191-9019

\begin{abstract}
The aim of this study is to examine the role of the use of stories in the transmission of cultural heritage by tourist guides. Today, sustainable values are prioritized. In this context, it is very important that the cultural heritage is also sustainable. In this respect, tourist guides are narrators who act as a bridge between cultural heritage and future generations. Therefore, in order to determine what role, the stories of the destinations play on the tourists, the tourist guides who have the opportunity to observe the reactions by telling these stories directly were interviewed. This study has been prepared as case study research which is one of the qualitative research methods. Data were collected via a semi-structured questionnaire from ten people who actively work as tourist guides. The obtained data were analyzed by content analysis. According to the findings of the study; storytelling makes the process of transferring cultural heritage much more engaging, catchy, entertaining and informative. On the model, the roles of storytelling in terms of both tourist guides (narrator) and tourists (listeners) are given. The outputs after storytelling are examined in the context of tourists, tourist guides and cultural heritage.
\end{abstract}

Keywords: Storytelling, Tour Guide, Cultural Heritage.

Received: 29.06 .2021

Accepted: 04.09.2021

\section{Suggested Citation:}

Kaya, B. and Ünlüönen, K. (2021). The Role of Storytelling on Cultural Heritage Transfer of Tourist Guides, Journal of Turkish Tourism Research, 5(3): 2166-2179.

(C) 2021 Türk Turizm Araştırmaları Dergisi. 


\section{Gíriş}

Postmodernizm sonrası deneyim oluşturma, tüketiciyi üretici konumuna getirme ve etkileşim oldukça önemli bir hal almıştır (Kotler vd., 2020). Bu nedenle, turizm söz konusu olduğunda zenginleştirilmiş içerikler kullanmak gerekmektedir. Hikâye anlatıcıllğ 1 ile ise turistlerde unutulmaz deneyimler oluşturmak, sürece dahil etmek ve etkileşim kurmak mümkündür (Kaya, 2020). Özellikle kültürel miras açısından, hikâyelerin aktarımı oldukça ilgi çekici ve etkili bir araçtır. Turist rehberleri, birçok görev üstlenmektedir. Ancak bunların içinde en temeli, anlatıcı olmalarıdır. Turist rehberleri, güçlü iletişim kurabilen ve çoğu kez sıkıcı gelen tarihi olayları ve mekanları anlatırken dikkati toplayabilen konumda olması gerekmektedir. Öyle ki, turist rehberlerinin anlatımları ve kurdukları iletişim, doğrudan turist deneyimlerini de etkilemektedir (Büyükkuru ve Aslan, 2015). Turist rehberlerinin, özellikle somut olmayan kültürel miras aktarımında hikâye kullanımının oldukça önemli olduğu bilinmektedir. Bunun yanı sıra, somut kültürel mirasın aktarımında da hikâyeler, turistlerin ilgisini çekmek ve daha unutulmaz bir deneyim yaratmak adına kullanılabilmektedir (Weiler ve Walker, 2014). Vaujany vd., (2018) yaptıkları araştırma sonucunda, turist rehberlerinin anlatımlarını dört aşamada gerçekleştirdiğini ele almıştır. Bu aşamalar; başlangıç, metalaştırma, seçim ve oyunlaştırmadır. Özellikle metalaştırma aşamasında, mekanları ve kültürleri deneyimlemenin en etkili yolu olarak hikâye anlatıcılığı gösterilmektedir. Deneyimin yanı sıra kültürel aktarımların turistlerin sürdürülebilirlik algısına da etki ettiği ortaya konmuştur. Kültürel aktarıma maruz kalan turistlerin, yerel kültürü anlamaya ve saygılı olmaya yöneldiği görülmüştür (Bidder vd., 2016). Literatürde yer alan bu çalışmalardan yola çıkarak turist rehberlerinin kültürel miras aktarımında hikâye anlatıcıllğının önemi görülmüştür. Ancak yine literatür incelendiğinde bu önemin temellerinin geniş bir çerçevede incelenmediği ve bu konuda eksikliklerin olduğu anlaşılmıştır. Buna dayanarak, kültürel miras aktarımında hikâye anlatıcılığının turist rehberleri için öneminin ve rolünün ne olduğu çalışmanın problemini oluşturmaktadır. Elde edilecek bulgu ve sonuçların turist rehberleri başta olmak üzere tur planlayıcı ve sağlayıcıların yol göstericisi olacağı düşünülmektedir.

Söz konusu çalışma ile turist rehberlerinin kültürel miras aktarımı esnasında hikâye anlatımının rolünü incelemek amaçlanmıştır. Sürdürülebilir yaklaşımın benimsenmesi ile kültürel mirasın etkili aktarımı oldukça önemli hale gelmiştir ve turist rehberlerine oldukça önemli bir görev düşmektedir. Bu nedenle, çalışmada turist rehberlerinin kültürel miras aktarımında hikâye anlatıcılığının rolüne odaklanılmıştır. Hikâye anlatıcılığının, kültürel miras aktarımında nasıl bir rolü olduğu tartışma, sonuç ve öneriler bölümünde bulgular ışığında yorumlanacaktır. Söz konusu durum da çalışmanın önemini ortaya koymaktadır.

Kavramsal olarak, turist rehberlerinin birçok rolü bulunmasına rağmen konu ile ilişkili olarak yalnızca anlatıcı rolü ele alınmıştır. Hikâye anlatıcılı̆̆ı ve kültürel miras konuları ise oldukça kapsamlıdır. Ancak yalnızca tüm kavramlar ilişkilendirilebilecek şekilde sınırlandırılmıştır. Hikâye anlatıcılığı bağlamında; mitler, efsaneler, rivayetler ele alınmıştır.

\section{Kültürel Miras}

"Miras" kavramı, UNESCO tarafından geçmişin geleceğe taşınan izleri olarak tanımlanmaktadır. Kültürel miras ise yapılaşmış ve tarihi çevreyi meydana getiren mimari değeri olan anıtlar ve yapılar olarak tanımlanmaktadır (UNESCO, 1972). Kültürel miras, toplumlara geçmişten kalan, günümüzde ortaya çıkarılan ve gelecek nesillerin yararına bahşedilen zengin kaynaklar sağlayan bir ürün ve süreçtir. En önemlisi, yalnızca somut değil, aynı zamanda doğal ve somut olmayan mirasları da içerir. Bununla birlikte, bu kaynaklar "kırılgan bir zenginliktir" ve bu nedenle, 
çeşitliliğini ve benzersizliğini koruyan ve bunlara saygı duyan politikalar ve geliştirme modelleri gerektirirler, çünkü bir kez kaybedildiklerinde yenilenemezler (UNESCO, 2014).

Kültürel miras; insan faaliyetlerinin tarihini, fikirlerini ve tutumlarını yansıtan; sosyal ve kültürel tarihi ve gelenekleri, mimariyi ve yapılı çevreyi kapsayan ve çevreyi tanımlamak için kullanılan ortak bir terimdir (Edwards ve Munshi, 2005: 8).

Kültürel mirası, dünyanın farklı bölgelerinde geçmişten beri yaşayan insan topluluklarının gelecek ile geçmiş arasında bir bağ kurmalarını sağlamakta, biriken değerleri kuşaktan kuşağa aktararak nesiller arası iletişim için bir köprü oluşturmaktadır. Toplumlardaki aidiyet ve bağlllık duygularını pekiştiren kültürel miras değerleri, insanları bir arada tutarak ortak bağları güçlendiren önemli unsurlardır (Sarıkaya Levent, 2011: 116).

Öte yandan kültürel mirasın uluslararası sözleşmelerdeki tanımına bakıldığında 16 Kasım 1972 tarihinde UNESCO tarafından kabul edilen Dünya Kültürel ve Doğal Mirasın Korunmasına Dair Sözleşme'nin 1. ve 2. maddeleri kültürel miras ve doğal mirası şu şekilde tanımlar (UNESCO, 1972): Madde 1- Bu sözleşmenin amaçları bakımından aşağıdakiler, "kültürel miras" sayılacaktır:

- Anıtlar: Tarih, sanat veya bilim açısından istisnaî evrensel değerdeki mimari eserler, heykel ve resim alanındaki şaheserler, arkeolojik nitelikte eleman veya yapılar, kitabeler, mağaralar ve eleman birleşimleri.

- Yapı toplulukları: Mimarileri, uyumlulukları veya arazi üzerindeki yerleri nedeniyle tarih, sanat veya bilim açısından istisnaî evrensel değere sahip ayrı veya birleşik yapı toplulukları.

- Sitler: Tarihsel, estetik, etnolojik veya antropolojik bakımlardan istisnaî evrensel değeri olan insan ürünü eserler veya doğa ve insanın ortak eserleri ve arkeolojik sitleri kapsayan alanlar.

1972 yılında kabul edilen bu sözleşme kültürel ve doğal mirasın korunmasına yönelikken 1998 yılında "İnsanlığın Sözlü ve Somut Olmayan Kültürel Miras Başyapıtları İlanı" ile yalnızca somut değerlerin değil somut olmayan değerlerin de kültürel miras kapsamında ele alınmasının zemini hazırlanmıştır (Yıldız, 2020). Bu ilan sonrasında, insan odaklı bakış açısıyla kurulan sivil toplum kuruluşları ile somut ve somut olmayan kültürel mirasın korunması ve sürdürülebilirliği hakkında çalışmalar yapılmaktadır. 2003 yılında ise "Somut Olmayan Kültürel Mirasın Korunması" sözleşmesi hazırlanmıştır (Oğuz, 2013). Somut olmayan miraslar; yerel halkın yaşama biçimi, sözel anlatı ve hikâyeler, el işleme eserleri, gelenek ve göreneklerden oluşmaktadır (Gümüş, 2020).

\section{Hikâye Anlatıcılığı}

Hikâyeler en eski iletişim araçlarından biridir ve çok önemlidir (McCabe ve Foster, 2006: 194). Mathews ve Wacker (2009: 190), hikâye anlatımının bilgiyi aktarmanın etkili bir yolu olduğuna dikkat çekmiştir. Hikâye anlatııılığının amacını ortaya çıkaran temel unsurlar şunlardır: keşfetmek, tanımlamak ve açılamak (Prince, 2012: 163).

Hikâyeler, kültürel miras turizminin sürdürülebilir gelişiminde önemli bir faktördür ve insanlık tarihi boyunca efsaneleri, kültürü, kahramanlıkları ve ritüelleri gelecek nesillere aktarmada bir araç olarak hizmet etmektedir (Dönmez ve Güler, 2016; Uygur, Demirer ve Hatırnaz, 2017). Ayrıca kültürel değerleri içeren hikâyeler de turistik olarak kullanılmaktadır, çoğu müze ve sergide hikâyeler turist rehberlerinin en önemli aracıdır (Mossberg, 2008).

Hikâye, destinasyonu keşif için açı ve çekici hale getirmektedir (Hsu, Dehuang ve Woodside, 2009). Destinasyonda aktarılan hikâyeler genellikle turistler tarafından sosyal medya aracılığıyla başkaları ile paylaşılmaktadır (Lund, Cohen ve Scarles, 2018). Bu tür gönderiler ise insanların 
dikkatini destinasyonlara çekmek için önemli bir araçtır (Hsiao, Lu ve Lan, 2013). Bu bağlamda destinasyon pazarlama sürecinde hikâyelerin kullanılmasının benzersiz bir turizm imajı oluşturacağı görülmektedir (Chronis, 2012).

Frost vd. (2020), çalışmalarında kültürel mirasın hikâyeler aracılığı ile anlatılmasının kusursuz bir turizm aracı olacağını belirtmiştir. Shouk ve Saliman (2021) ise turizmde özellikle mekanlarda deneyim yaratma bağlamında kullanılabilecek bir diğer araç olan oyunlaştırmaya dikkat çekmektedir. Oyunlaştırmanın temelinde ise hikâye anlatıcılığının mutlaka yer alması gerektiği vurgulanmıştır. Rehberli turlarda anlatıma eşlik etmesi için hikâye anlatıcılığından yararlanılarak hazırlanan animasyonların ise turistlerin deneyimi ve memnuniyeti ile ilişkili olduğu ortaya konmuştur (Wu vd., 2019). Özetle hikâye anlatıcılığının, kültürel miras aktarımında turist üzerinde farklı rolleri olabileceği literatürde de yer almaktadır. Özellikle turistlerin, rehberli turlarda deneyim yaratabilmesi ve memnuniyet düzeyinin artması için hikâye anlatımının önemi vurgulanmıştır. Buna ek olarak, oyunlaştırma temelli animasyon, arttırılmış ve sanal gerçeklik uygulamalarının kullanımında da hikâye anlatıcılığı mutlaka yer alması gereken bir araç olarak görülmektedir.

Hikâye anlatıcılığı kapsamında hikâyeler; mitler, efsaneler, masallar, destanlar söylenceler, dedikodular, törenler, ritüeller, dizi ve film senaryoları ele alınabilmektedir. Bunun nedeni ise anlatılan her şeyin Jahn (2015: 43) tarafından hikâye olarak tanımlanmasıdır.

\section{Turist Rehberlerinin Anlatıcı Rolü}

Her hikâyenin bir anlatıcıya ihtiyacı vardır (Prens, 2012: 16). Ancak anlatııı her zaman olayın gerçek deneyimcisi olmak zorunda değildir (Prens, 2012: 68). Anlatıcı, hikâyenin yayılmasında aracı bir rol üstlenirken, kahraman ve anlatıcı da hikâyedeki kişisel deneyimleri aktaran kişilerdir (Boje, 2001: 5). Olayları aktarmak; anlatıcıya olayı kendi hayalinde bile yaşama fırsatı verir, bu şekilde anlatıcı daha önce yaşamadığı bir olayı yaşamış hissine kapılır ve böylece başkaları da olayı deneyimleyebilmektedir (Sütçü, 2013). Hikâye, anlatıcının karakterleri, duyguları ve düşünceleri kullanarak anlattığı bir olay ve olaylar dizisidir (Prince, 2012: 68).

Her anlatıcının ilk görevi seyirciyle doğru iletişim kurmaktır. İzleyici kazanılmazsa hikâyenin kalitesi önemli olmayacaktır (Mathews ve Wacker, 2009: 39). Bu durumda hikâyenin etkililiği onu dinleyen izleyiciye bağlıdır.

Turizm hikâyelerinde anlatıcılar turizm faaliyetlerini oluşturan ve bu faaliyetlere katılım sağlayan tüm paydaşlar olabilmektedir. Profesyonel turist rehberleri, örgüt çalışanları, turistler, pazarlamacılar bunlara örnek olarak verilebilir (Kaya, 2020). Aktaş ve Batman (2010) yaptıkları çalışma ile turist rehberleri aracılığ 1 ile aktarılan efsanelerin, destinasyonlarda çekicilik unsuru oluşturduğunu ortaya koymayı amaçlamışlardır. Sonuç olarak ise rehberler tarafından aktarılan efsanelerin turistler üzerinde çekicilik etkisi oluşturabileceğini ancak bu noktada, turist rehberinin iletişim konusundaki becerilerinin (ses tonu, jest ve mimikler, göz kontağ1 vb.) ve konuya olan hâkimiyetinin önemli olduğunu ortaya koymuşlardır. Bu bağlamda; aktarılacak bir hikâyenin, dinleyici kitlesini etkisi altına alabilmesi açısından anlatıcının rolünün çok büyük olduğu söylenebilmektedir. Bu nedenle de turist rehberlerinin, tur esnasinda yararlandığ 1 hikâyeleri aktaran anlatıcılar olarak, daha bilinçli ve kontrollü olması gerekmektedir.

Literatürden elde edilen kuramsal yaklaşıma göre, hikaye anlatcılığı ve rehberlerin anlatıcı rolünün pek çok açıdan ilişkili olduğu görülmüştür. Bu yargıdan hareketle hikaye anlatıcılığının turist rehbeleri açısından rollerini derinlemesine incelemek amaçlanmıştır. Bu şekilde elde edilen sonuçlar ile turist rehberlerine yol gösterici olacağı düşünülen bu çalışma önem kazanmaktadır. 


\section{YÖNTEM}

Araştırma nitel yönteme dayanmaktadır. Nitel yöntemlerden durum çalışma deseni benimsenmiştir. Durum çalışma deseni; sorgulama değil, durumları anlayarak yorumlama fırsatı sunmaktadır. Ayrıca durum çalışmaları, her nitel araştırma deseninde olduğu gibi genelleme kaygısı gütmeden, söz konusu durumun derinlemesine anlaşılmasını ortaya koymaktadır (Denzin ve Lincoln, 2005:443). Nitel yöntem felsefi yaklaşımlarından biri olan sosyal yapı benimsenmiştir. Benimsenen felsefe, anlam arayışına ve sosyal etkileşim konuları temeline dayanmaktadır. Üstelik bu felsefe, kolektif bir süreçtir (Denzin ve Lincoln, 2005:509). Araştırma süresince geçerlilik ve güvenilirlik bağlamında etik konular dikkate alınmıştır. Araştırmanın geçerliliğini sağlamak adına iki akran değerlendirmesi gerçekleştirilmiştir. Bu bağlamda, çalışmanın analizi açısından geçerliliğin sağlandığı söylenebilmektedir. Güvenilirlik bağlamında ise, kod anlamları değiştirilmemiş, süreç açıklıkla belirtilmiş ve tüm görüşme belgeleri kayıt altına alınmıştır.

Çalışmanın amacı, turist rehberlerinin kültürel miras aktarımı esnasında hikâye anlatımının rolünü incelemektir. Hikâyelerin ve rehberlerina anlatıcı rolünün kültürel miras aktarımı bağlamında rolünü incelemek, uygulanabilirlik açısından da önem taşımaktadır. Bu durum çalışmanın da önemini ortaya koymaktadır. Söz konusu çalı̧̧ma sonucunda, hikaye anlatıcılığının hangi rollerinin nasıl bir süreçle işlenmesi gerektiği ortaya konacaktır. Turist rehberlerine yol gösterici niteliğinde olacak bu çalışma bu yönüyle önem taşımaktadır.

Çalışmanın amaç ve önemine yönelik olarak geliştirilen araştırma soruları aşağıda yer aldığı gibidir:

- Turist rehberleri, kültürel mirasın aktarımında hikâye kullanımını etkili bir araç olarak görüyor mu?

- Hikâyeler, turistler üzerinde kültürel miras bağlamında ne gibi etkiler bırakıyor?

- Hikâye anlatımının, turist rehberlerine ne gibi faydaları olmaktadır?

- Hikâyeler, kültürel mirası daha akılda kalıcı hale getiriyor mu?

- Turistler, hikâyeler karşısında nasıl bir tutum sergiliyor?

\section{Evren ve Örneklem}

Araştırmanın evrenini, profesyonel turist rehberleri oluşmaktadır. Nitel araştırmalar için evreni temsil eden örneklem, tekrara düşen yanitlar alınana kadar görüşmeye devam ederek belirlenmektedir (Yıldırım ve Şimşek, 2008). Bu bağlamda, söz konusu çalışmada 16 profesyonel turist rehberi ile görüşülmüştür. Örnekleme yöntemi olarak kartopu örnekleme kullanılmıştır.

\section{Veri Toplama Aracı ve Süreci}

Görüşme soruları literatürden destek alınarak, profesyonel turist rehberlerinin hikâye anlatıcllğ 1 ve hikâyelerin kültürel miras aktarım aracı olarak kullanım rolünün incelenmesi amacıyla hazırlanmıştır. Hazırlanan görüşme soruları, uzman görüşü alınarak son kullanım halini almıştır. Sorular yarı yapılandırılmış formda hazırlanmıştır. Kullanılan sorular aşağıdaki gibidir:

1. Kültürel mirasın turistlere aktarılmasını önemsiyor musunuz, neden?

2. Kültürel mirasın sürdürülebilirliğinde anlatıcı rolünde olmak size nasıl hissettiriyor? 
3. Sizce kültürel mirasın turistlere aktarılmasında hikâyeler (efsane, mit, söylence vb.) nasıl bir rol oynamaktadır?

4. Hikâye anlatıcılığının kültürel mirası daha akılda kalıcı hale getirdiğini düşünüyor musunuz, neden?

5. Hikâyeler anlatarak tanıttığınız kültürel miras öğelerine karşı turist tutumlarını nasıl yorumluyorsunuz?

6. Kültürel miras aktarımında hikâye kullanmayı sever misiniz, neden?

7. Kültürel mirasın aktarımında hikâye kullanmanın sizin için ne gibi faydaları olmaktadır?

Yukarıda yer alan sorular, görüşme yolu ile belirlenen katılımcılara yöneltilerek veriler elde edilmiştir. Görüşmeler, yüz yüze ve salgın nedeni ile çevrimiçi yöntemler kullanılarak gerçekleştirilmiş olup, tüm görüşmeler kayıt altına alınmıştır. Araştırma 2021 yılının Mart ayında yürütülmüştür.

\section{Veri Analizi}

Hazırlanan yarı yapılandırılmış görüşme soruları katılımcılara yöneltilmiştir. Görüşme sonucu 16 katılımcıdan elde edilen veriler için içerik analizi kullanılmıştır. Verilen yanıtlar kodlanarak temalar oluşturulmuştur. Bunun için seçici kodlama türü benimsenmiştir. Tüm kodlar ele alınıp ana temalar bu kodlara göre oluşturulmuştur.

\section{BULGULAR}

Araştırma verileri analiz edilirken öncelikli olarak tanımlayıcı bulgulara aşağıda yer alan Tablo 1 üzerinde yer verilmiştir. Katılımcıların 11'inin erkek, beşinin ise kadın olduğu görülmektedir. Yaş aralıkları ise 24 ila 59 arasında değişmektedir. Eğitim düzeyleri açısından ele alındığında örneklemin yarısı lisans, altısı yüksek lisans, biri doktora ve biri ise lise düzeyindedir. Çalışma süreleri ise 1 ila 36 yll arasında değişmektedir.

Tablo 1. Katılımcıların Tanımlayıcı Bulguları

\begin{tabular}{lrrrr}
\hline KATILIMCI & YAŞ & CiNSIYYET & EĞITIM DURUMU & KAÇ YILDIR REHBERLiK YAPIYOR? \\
\hline K1 & 29 & Erkek & Doktora & 3 yıl \\
\hline K2 & 28 & Erkek & Lisans & 1 yll \\
\hline K3 & 29 & Erkek & Lisans & 4 yll \\
\hline K4 & 24 & Kadın & Yüksek Lisans & 1 yıl \\
\hline K5 & 40 & Erkek & Lisans & 13 yıl \\
\hline K6 & 34 & Kadın & Lisans & 6 yll \\
\hline K7 & 36 & Erkek & Lisans & 11 yll \\
\hline K8 & 59 & Kadın & Lisans & 36 yıl \\
\hline K9 & 42 & Kadın & Yüksek Lisans & 20 yll \\
\hline K10 & 28 & Erkek & Yüksek Lisans & 2 yll \\
\hline K11 & 53 & Kadın & Lise & 22 yıl \\
\hline K12 & 49 & Erkek & Ön Lisans & 28 yll \\
\hline K13 & 33 & Erkek & Lisans & 7 yll \\
\hline K14 & 26 & Erkek & Yüksek Lisans & 2 yll \\
\hline K15 & 28 & Erkek & Yüksek Lisans & 2 yll \\
\hline K16 & 28 & Erkek & Yüksek Lisans & 2 yll \\
\hline
\end{tabular}


"Kültürel mirasın turistlere aktarılmasını önemsiyor musunuz, neden?" sorusuna verilen yanıtlar, içerik analizi ile kodlanarak, temalar oluşturulmuştur. Verilen yanıtlara göre oluşturulan temalar; sürdürülebilirlik, değer, pazarlama ve mesleki olarak ortaya konmuştur. Aşağıda yer alan Tablo 2 üzerinde kodlama ve temalara yer verilmiştir. Katılımcılardan yalnızca bir kişi kültürel mirası önemsemediğini belirtirken, diğer tüm katılımcılar oldukça önemli olduğunu vurgulamıştır. Hatta öyle ki, K6 "Kültürler ve nesiller arasında köprü görevindeyiz" söylemi ile hem mesleklerinin hem de sürdürülebilirliğin bir parçası olduğunu vurgulamıştır.

Tablo 2. Turist Rehberlerinin Kültürel Miras Aktarımına Gösterdikleri Önem

\begin{tabular}{|c|c|c|c|}
\hline $\begin{array}{l}\text { Önemseme } \\
\text { Durumu }\end{array}$ & Katılımcılar & Temalar & Kodlamalar \\
\hline \multirow{3}{*}{$\begin{array}{l}\text { Önemseyenler } \\
\text { K1-K2-K3-K4-K6- } \\
\text { K7-K8-K9-K10-K11- } \\
\text { K12-K13-K14-K15- } \\
\text { K16 }\end{array}$} & $\begin{array}{l}\text { K1-K4-K6- } \\
\text { K7-K16 }\end{array}$ & $\begin{array}{l}\text { Sürdürülebilirli } \\
\mathrm{k}\end{array}$ & $\begin{array}{l}\text { Geleceğe aktarım, Mirası koruma, } \\
\text { kültüre sahip çlkma duygusu } \\
\text { yaratma, mirası ölümsüz kılmak, } \\
\text { uzun süreli aktarım sağlama, kültürel } \\
\text { miras aktarımı }\end{array}$ \\
\hline & K2-K14 & Değer & $\begin{array}{l}\text { Değer yaratma, insanlığın ortak } \\
\text { değeri }\end{array}$ \\
\hline & $\begin{array}{l}\text { K2-K3-K7- } \\
\text { K11-K12 }\end{array}$ & Pazarlama & $\begin{array}{l}\text { Kültürü yansıtma, turistte bilinç } \\
\text { yaratma, turistte fikir oluşturma, } \\
\text { tanıtım, kültürü tanıtma, kültür ve } \\
\text { varlığı tanıtma, toplulukları tanıtmak }\end{array}$ \\
\hline $\begin{array}{l}\text { Önemsemeyen } \\
\text { K5 }\end{array}$ & $\begin{array}{l}\text { K9-K13-K15- } \\
\text { K16 }\end{array}$ & Mesleki & $\begin{array}{l}\text { Bölgelerin bölünemez parçası, } \\
\text { rehberlerin çalışma amacl, turizmin } \\
\text { bir parçası, Anadolu'nun kültür } \\
\text { zenginliği }\end{array}$ \\
\hline
\end{tabular}

"Kültürel mirasın sürdürülebilirliğinde anlatıcı rolünde olmak size nasıl hissettiriyor?" sorusuna verilen yanıtlar ise duygusal, hazcılık ve psikolojik temalar ile tanımlanmıştır. Katılımcıların büyük bir çoğunluğu, olumlu duygular oluşturduğunu belirtmiştir. Örneğin K7; "Anlatılmaz yaşanır desek doğru olur. Her seferinde ayrı heyecan, her seferinde yeniden başlar gibi..." ifadesi ile anlatıcı rolünde olmayı benimsediğini ve duygusal olarak oldukça tatmin edici bulduğunu belirmektedir.

Tablo 3. Turist Rehberlerinin Anlatıcı Rolünde Olmalarındaki Hisleri

\begin{tabular}{lll}
\hline Katılımcılar & Temalar & Kodlamalar \\
\hline $\begin{array}{l}\text { K1-K3-K4-K9-K10- } \\
\text { K11-K12-K14 }\end{array}$ & Duygusal & $\begin{array}{l}\text { Güzel duygu (5), mutluluk verici, duygu yüklü, } \\
\text { keyifli, muhteşem }\end{array}$ \\
\hline $\begin{array}{l}\text { K1-K2-K5-K6-K7- } \\
\text { K15 }\end{array}$ & Hazc1lı & $\begin{array}{l}\text { Zevk verici, heyecan verici (2), onur verici (2), ego } \\
\text { tatmini }\end{array}$ \\
\hline K1-K8-K13 & Psikolojik & Ayrıcalıklı hissetme, şanslı hissetme, güçlü özellik \\
\hline
\end{tabular}

"Sizce kültürel mirasın turistlere aktarılmasında hikâyeler (efsane, mit, söylence vb.) nasıl bir rol oynamaktadır?" sorusuna verilen yanıtlar ise aşağıda yer alan Tablo 4 üzerinde gösterilmiştir. 
Profesyonel turist rehberlerine göre hikâyelerin, kültürel miras aktarımındaki rolü; odaklanma, bilişsel, duygusal, devamlılık ve sosyalleşme temalardan oluşmaktadır. Özellikle bilişsel ve odaklanma faktörleri oldukça vurgulanmaktadır. Örneğin; K1, K4 ve K7 hikâyelerin destinasyonları hatırlanabilir kıldığını belirmiştir. Ancak bunun dışında zaman zaman ilginin dağılmasına da neden olduğu sonucuna ulaşılmıştır. Örneğin; K8 ve K15 abartılmadan, gerekli olduğu yerde hikâye kullanımının çok daha etkili ve dikkat çekici olduğunu vurgulamaktadır.

Tablo 4. Rehberlere Göre Hikâyelerin Kültürel Miras Aktarımındaki Rolü

\begin{tabular}{lll}
\hline Katılımcılar & Temalar & Kodlamalar \\
\hline K1-K4-K7-K12-K15-K16 & Odaklanma & $\begin{array}{l}\text { Akılda kalıcı (3), dikkat toplayıcı, odaklanma } \\
\text { sağlayan }\end{array}$ \\
\hline $\begin{array}{l}\text { K1-K5-K6-K7-K13-K14- } \\
\text { K16 }\end{array}$ & Bilişsel & İlgi çekici (5), merak uyandıran (2) \\
\hline K3-K5-K9-K10-K12 & Duygusal & Eğlenceli (2), heyecanlı kılma, etkileyici (2) \\
\hline K6-K8 & Devamlılık & Sürükleyici ve akıcı kılma \\
\hline K1-K5-K16 & $\begin{array}{l}\text { Sosyalleşm } \\
\text { e }\end{array}$ & Fotoğraf ve videolama, sosyal medya paylaşımı \\
\hline
\end{tabular}

"Hikâye anlatıcılığının kültürel mirası daha akılda kahıcı hale getirdiğini düşünüyor musunuz, neden?" sorusuna verilen yanıtlar ise bilişsel, odaklanma, duygusal, grup profili ve sosyalleşme temalarını ortaya koymaktadır. Bu soruda özellikle vurgulanan nokta hikâyelerin akılda kalıcı olmasını etkileyen temel nedenlerin grup profiline bağlı olduğudur. Öyle ki; K8, K12 ve K13 grup farklılıklarının beklentileri değiştirdiğini ve bazı grupların, sosyalleşmekten uzak dururken bazı grupların yalnızca bilgi almak istediklerini belirtmişlerdir. Bu bağlamda, hikâyelerin herkes için akılda kalıcı olmasını beklemek mümkün değildir.

Tablo 5. Rehberlere Göre Hikâyelerin Kültürel Mirası Daha Akılda Kalıcı Hale Getirme Nedenleri

\begin{tabular}{lll}
\hline Katılımcılar & Temalar & Kodlamalar \\
\hline $\begin{array}{l}\text { K1-K3-K4-K5-K9-K10-K11- } \\
\text { K15 }\end{array}$ & Bilişsel & İlgi çekici (6), bilgi aktarımı, somutlaştırma \\
\hline K7-K14 & Odaklanma & Odaklanma sağlaması, dikkat toplayıcı \\
\hline K2-K5-K6-K9 & Duygusal & $\begin{array}{l}\text { Duygu yüklü olması, eğlenceli, içselleştirme, } \\
\text { zevkli }\end{array}$ \\
\hline K8-K12-K13 & Grup Profili & $\begin{array}{l}\text { Grup farklıllkları, sosyal grup, bilgi odaklı } \\
\text { grup }\end{array}$ \\
\hline K16 & Sosyalleşme & Tur sonrası paylaşımlar ve yorumlar \\
\hline
\end{tabular}

"Hikâyeler anlatarak tanıttı̆̆ınız kültürel miras öğelerine karşı turist tutumlarını nasıl yorumluyorsunuz?" sorusuna verilen yanıtlar aşağıda yer alan Tablo 6 üzerinde yer almaktadır. Turistlerin tutumları bilişsel, duygusal ve değişkenlik temaları altında ele alınmıştır. Bir önceki soruda yer alan, grup profilinin çıktısı olarak burada değişkenlik teması görülmektedir. Her turistin beklentisinin aynı olmaması ve konunun farklılıkları turist tutumlarını etkileyen unsurlar olarak görülmektedir. Ancak bu değişkenliğe rağmen, büyük bir çoğunluğun hem bilişsel hem de duygusal olarak sürece dahil olduğu da görülmektedir. Öyle ki, K1 “Bilinçlenme olduğu kesin. 
Hem kültürel mirasın korunduğunu hem de ziyaretçilerin miras algısının yükseldiğini söyleyebilirim" ifadesi ile turistlerin tutumunun hikâyelerden etkilendiğini ortaya koymuştur.

Tablo 6. Hikâyeler Aracılığı ile Tanıtan Kültürel Mirasa Karşı Turist Tutumları

\begin{tabular}{lll}
\hline Katılımcılar & Temalar & Kodlamalar \\
\hline $\begin{array}{l}\text { K1-K4-K5-K6-K7-K9-K13- } \\
\text { K15-K16 }\end{array}$ & Bilişsel & $\begin{array}{l}\text { Bilinçlenme, zengin bakış açıSı, } \\
\text { anlamlandırma, ilgili, meraklı dikkatli, } \\
\text { empati yapabilen, odaklanma }\end{array}$ \\
\hline K3-K7-K8-K10-K12-K16 & Duygusal & $\begin{array}{l}\text { Hoş karşılama, istekli, hayranlık duyma, } \\
\text { mekana bağlılık ve aidiyet, umursamaz }\end{array}$ \\
\hline K2-K11 & Değişkenlik & $\begin{array}{l}\text { Konu farklılıkları, turist beklentileri, hikâye } \\
\text { farklılıkları }\end{array}$ \\
\hline
\end{tabular}

"Kültürel miras aktarımında hikâye kullanmayı sever misiniz, neden?" sorusuna verilen yanıtlar, aşağıda yer alan Tablo 7 üzerinde verilmiştir. Turistlerin kültürel miras kullanma nedenleri "Olumlu", kullanmama nedenleri ise "Olumsuz" olarak temalandırılmıştır. Katılımcıların çoğu, hikâyeleri anlatım bağlamında güçlü bir araç olarak nitelendirirken, K8-K9-K13 genellikle salt bilgi aktarımının daha doğru olduğunu ve hikâye anlatımına pek yakın olmadıklarını belirtmişlerdir. Bunun nedeni olarak K13 “Hikâye anlatımı, sahip olduğumuz kültürel ve tarihi değerleri soyutlaştırıp, değersizleştiriyor. Batı kültüründe sahip olunan tarihin anlatımı hikâyeler üzerinden yürür. Fakat bizim bunları kullanmaya gerek duymayacak kadar heybemiz dolu. Dünyada bizim kültür ve tarihimize dokunmadan, tarih ve kültür inşa etmek mümkün olmamışırı" söylemi ile hikâye anlatımının kültürün ve tarihin yetersiz kaldığı noktada kullanılması gerektiğini vurgulamıştır.

Tablo 7. Turist Rehberlerinin Kültürel Miras Aktarımında Hikâyeleri Kullanma Nedenleri

\begin{tabular}{lll}
\hline Katılımclar & Temalar & Kodlamalar \\
\hline $\begin{array}{l}\text { K1-K2-K3-K4-K5-K6-K7- } \\
\text { K9-K10-K11-K12-K14-K15- }\end{array}$ & Olumlu & $\begin{array}{l}\text { Güçlü anlatım, akılda kalıcı, dikkat toplayıc1, } \\
\text { eğlenceli, ilgi çekici, turisti konuya dahil } \\
\text { eden, çeşitlilik sağlayan, merak uyandıran, } \\
\text { etkili }\end{array}$ \\
\hline K8-K9-K13 & Olumsuz & $\begin{array}{l}\text { Fazla kullanımı dikkat dağıtan, } \\
\text { değersizleştiren, soyutlaştıran }\end{array}$ \\
\hline
\end{tabular}

"Kültürel mirasın aktarımında hikâye kullanmanın sizin için ne gibi faydaları olmaktadır?" sorusuna verilen yanıtlar, aşağıda yer alan Tablo 8 üzerinde incelenmiştir. Kültürel miras aktarımında hikâye kullanımın profesyonel turist rehberlerine faydaları beş tema altında toplanmıştır. Bunlar; anlatım, iletişim, bilişsel, duygusal ve pazarlamadır. Özellikle profesyonel turist rehberleri açısından ele alındığında anlatım ve iletişim boyutunun önemi yadsınamazdır. Katılımcların büyük bir çoğunluğu ise bilişsel boyutu vurgulamış ve en çok faydanın bu boyut ile sağlandığını belirtmiştir. Öyle ki; K1, "Anlatımı güçlendiriyor, konuların içini doldurabiliyorsunuz, farkındalık oluşturabiliyorsunuz. Hatta destinasyon sadakati sağladığını da düşünüyorum" söylemi ile bilişselliğin öneminin yanı sıra pazarlama boyutunu da vurgulamıştır. 
Tablo 8. Kültürel Miras Aktarımında Hikâye Kullanımının Turist Rehberlerine Faydaları

\begin{tabular}{lll}
\hline Katılımcılar & Temalar & Kodlamalar \\
\hline K1-K3-K4-K5 & Anlatım & $\begin{array}{l}\text { Güçlü anlatım, akıı anlatım, bilgiye } \\
\text { hakimiyet, zengin anlatım }\end{array}$ \\
\hline K2-K6-K8-K16 & İletişim & $\begin{array}{l}\text { Samimi ilişkiler, kolay iletişim, sorunlar } \\
\text { çözme, güçlü iletişim }\end{array}$ \\
\hline $\begin{array}{l}\text { K1-K3-K5-K6-K7-K9-K11- } \\
\text { K12-K15 }\end{array}$ & Bilişsel & $\begin{array}{l}\text { Farkındalık yaratma, ilgi uyandırma (3), } \\
\text { dikkat toplama (4), hatırlanabilir olma (2), } \\
\text { öğretici, odaklama sağlayıcı }\end{array}$ \\
\hline K6-K10 & Duygusal & Eğlenceli, duygu yaratan \\
\hline K1-K13-K14 & Pazarlama & $\begin{array}{l}\text { Destinasyon sadakati, değerin anlaşılması, } \\
\text { tur sonrası paylaşım ve yorum }\end{array}$ \\
\hline
\end{tabular}

\section{TARTIŞMA, SONUÇ ve ÖNERILLER}

Çalışmada özetle, grup profilinin hikâye anlatımını etkilediği sonucuna varılmıştır. Sosyal ya da bilgi odaklı grubun beklenti farklılıkları, turist rehberinin anlatımında hikâyelere yer verip vermeyeceğine karar vermesinde önemli bir etkendir. Turistlerin profil farklılıklarına göre beklentilerinin değişeceği görüşü Eryılmaz'ın (2020) gerçekleştirdiği çalışma ile örtüşmektedir.

Uygun grup profili sağlandığında, hikâye anlatımı gerçekleştiren turist rehberleri hem kendileri hem de turist açısından sürecin boyutlarını ortaya koymuşlardır. Bu bağlamda, anlatım esnasında turist rehberlerinin, kültürel mirası aktarmada anlatıcı rolünde olması duygusal tatmin, hazcılık ve psikolojik üstünlükler sağlamaktadır. Turist rehberleri, bu süreci olumlu bir doyum olarak yansıtırken, turistler ise süreçte odaklanma, bilişsel, duygusal, devamlılık ve sosyalleşme gibi boyutlarda etkilenmektedir. Çalışmadan elde edilen modelde, Green ve Brock (2000) tarafından geliştirilen "Anlatıya Ulaşım Teorisi” modeli temel alınmıştır. Araştırmacıların ortaya koyduğu modelde, hikâyeye ulaşım sağlaması üç boyuttan meydana gelmektedir. Bunlar; odaklanma, bilişsel ve duygusal boyutlardır. Gerçekleştirilen bu çalışmada ise, bulgular Green ve Brock modeline ek olarak devamlılık ve sosyalleşme boyutlarını da eklemektedir. Bu bağlamda, çalışmanın literatürde yer alan bu modeli turistler bağlamında geliştirebileceği söylenebilmektedir.

Son aşama olan anlatım sonrası çıktılar ise turistler, turist rehberleri ve kültürel miras bağlamında bölümlendirilmiştir. Turistler, kültürel miras bağlamında katıldıkları turlarda hikâye anlatımına maruz kalıyor ise bilişsel, duygusal ve pazarlama boyutunda çıtılar elde etmektedirler. Söz konusu boyutları açıklamak gerekirse, bilişsel açıdan değerlendirildiğinde tatilini daha hatırlanabilir kıldığını, duygular açısından incelendiğinde daha unutulmaz ve olağanüstü bir deneyime dönüştürdüğünü, pazarlama açısından incelendiğinde ise, turisti üretici-tüketici konumuna getirip, ağızdan ağıza pazarlama aracına dönüştürdügünü söylemek mümkündür. Elde edilen sonuç, Bryon (2012) tarafından yapılan çalışmadaki, hikâyelerin başkaları ile paylaşılmasında turist rehberlerinin etkisinin önemli olduğu sonucuyla da örtüşmektedir. Ayrıca, Zhong vd., (2017) ve Dönmez (2015) tur esnasında aktarılan hikâyelerin, paylaşım etkisinin yüksek olduğu sonucunu ortaya koymuştur. Bu sonuç, gerçekleştirilen bu çalışmayı destekler niteliktedir. Turist rehberleri bağlamında hikâye anlatımı sonrası çıtılar; anlatım, iletişim ve mesleki bütünlük boyutlarını sunmaktadır. Hikâyelerin anlatımı zenginleştirerek daha güçlü kıldığı ve iletişimi de kuvvetlendirdiği sonucu elde edilmiştir. Aynı zamanda hikâyeler ile kültürel mirası aktarmak, mesleki açıdan, rehberlerin göz ardı edilemez bir parçası görüldüğünden, mesleki bütünlük sağladığı da aşikardır. Kültürel mirasa yönelik anlatım 
sonrası çıktılar ise, sürdürülebilirlik, değer ve pazarlama boyutlarını oluşturmaktadır. Hikâyeler ile kültürel mirası aktarmak, oluşturduğu etki ve akılda kalıcı olması nedeniyle daha fazla paylaşıma neden olacaktır. Bu durum da hem pazarlama boyutunu hem de daha fazla kişiye aktarılması ile sürdürülebilirliğe etki etmektedir. Hikâyelerin değer yaratacağı görüşü Ganassali ve Matysiewicz (2020) tarafından yapılan çalışma ile örtüşmektedir. Yazarlar hikâyelerin, marka değeri üzerinde etkisi olduğunu ortaya koymuştur. Bu durum pazarlama açısından önemini de vurgulamaktadır. Frost vd., (2020)'ne göre de hikâye anlatıcılığı pazarlama bağlamında etkili bir araçtır. Ayrıca turist rehberlerine göre, hikâyeler destinasyonlardaki kültürel mirası daha değerli kılmaktadır. Bunun yanı sıra, unutulmaz deneyimler oluşturmasıyla turist açısından da değerli algılandığı görülmektedir. Bu bulgu Weiler ve Walker (2014) ile Vaujany vd., (2018) tarafından yapılan çalışmanın sonuçları ile örtüşmektedir.

Çalışma sonucundan yola çıkarak verilecek önerilerin başında, turist rehberlerinin hikâye kullanımının bilincine varmalarının gerekliliği yer almaktadır. Özellikle, seyahat acentaları ve tur operatörlerinin tanıtımlardan itibaren hikâye kullanımına yer vermeleri önemli bir gereklilik haline gelmiştir. Turist rehberleri ise sürecin bizzat yöneteni olarak, mutlaka grup profillerini göz önünde bulundurarak hikâyelerden yararlanmalı ve turistleri etkileşimli bir sürece dahil ederek, deneyimlerini unutulmaz kılmalı, değer oluşturmalı ve konu hakkında paylaşım yapmaya teşvik edici olmalıdır. Özelikle popüler hale gelmeye başlayan oyunlaştırma uygulamalarını tur programlarına dahil ederek hem kültürel miras hikâyelerini paylaşmalı hem de turistlerin kendi deneyimlerinden yaratacağı hikâyeleri destekleyerek sürdürülebilir bir döngü yaratmalıdır. Araştırma bulgularından elde edilen sonuca göre, turist rehberleri anlatı tasarımı gerçekleştirmeli, kültürel mirasa yapılacak katkılarda göz önünde bulunarak hareket edilmelidir. Rehberler ve turistler için etkileşim güçlendirilerek, temelde destinasyon hikayelerinden bir değer yaratmalı, kültürel miras sürdürülebilir kılınmalı ve turist tarafından pazarlama gücü oluşturulmalıdır.

\section{KAYNAKÇA}

Abou-Shouk, M. and Soliman, M. (2021). The Impact of Gamification Adoption Intention on Brand Awareness and Loyalty in Tourism: The Mediating Effect of Customer Engagement. Journal of Destination Marketing \& Management, 20, 100559.

Aktaş, S. ve Batman, O. (2010). Efsanelerin Turistik Çekicilik Üzerine Etkileri: Profesyonel Turist Rehberlerine Yönelik Bir Araştırma. E-Journal of New World Sciences Academy, 5(4), 367-395.

Bidder, C., Kibat, S. A. and Fatt, B. S. (2016). Cultural Interpretation Toward Sustainability: A Case of Mount Kinabalu. Procedia-Social and Behavioral Sciences, 224, 632-639.

Bryon, J. (2012). Tour Guides as Storytellers-From Selling to Sharing. Scandinavian Journal of Hospitality and Tourism, 12(1), 27-43.

Boje, D. M. (2001). Narrative Methods for Organizational \& Communication Research. California: Sage Publishing.

Büyükkuru, M. ve Aslan, Z. (2015). Turist Rehberlerinin İletişim Becerilerinin Turistlerin Tur Deneyimi Üzerine Etkisi: Nevşehir İlinde Bir Araştırma Mustafa Kemal Üniversitesi Sosyal Bilimler Enstitüsü Dergisi, 13(34).

Chronis, A. (2012). Between Place and Story: Gettysburg as Tourism Imaginary. Annals of Tourism Research, 39(4), 1797-1816. 
De Vaujany, F. X., Dandoy, A., Grandazzi, A. and Faure, S. (2019). Experiencing a new place as an atmosphere: A focus on tours of collaborative spaces. Scandinavian Journal of Management, 35(2), 1-12.

Denzin, N. K. and Lincoln, Y. S. (2005). Introduction: The Discipline and Practice of Qualitative Research. California: Sage Publishing.

Dönmez, M. (2015). Pazarlama İletişiminde Transmedya Uygulamaları: Örnek Olay İncelemeleri, Selçuk Üniversitesi, Sosyal Bilimler Enstitüsü, Doktora Tezi: Konya.

Dönmez, M. ve Güler, Ş. (2016). Transmedya Hikâyeciliği "Doritos Akademi" Örneği İncelemesi. Visionary E-Journal/Vizyoner Dergisi, 7(16), 155-175.

Edwards, H. G. and Munshi, T. (2005). Diagnostic Raman Spectroscopy for The Forensic Detection of Biomaterials and The Preservation of Cultural Heritage. Analytical and Bioanalytical Chemistry, 382(6), 1398-1406.

Eryılmaz, B. (2020). Turisti Tanımak: Yerli Turist Profili Üzerine Bir Araştırma. Türk Turizm Araştırmaları Dergisi, 4(3), 2327-2342.

Frost, W., Frost, J., Strickland, P. and Maguire, J. S. (2020). Seeking a Competitive Advantage in Wine Tourism: Heritage and Storytelling at the Cellar-Door. International Journal of Hospitality Management, 87, 102460.

Ganassali, S. and Matysiewicz, J. (2021). Echoing The Golden Legends: Storytelling Archetypes and Their Impact on Brand Perceived Value. Journal of Marketing Management, 37(5-6), 437-463.

Green, M. C. and Brock, T. C. (2000). The Role of Transportation in The Persuasiveness of Public Narratives. Journal of Personality and Social Psychology, 79(5), 701.

Gümüş, R. (2020). Çankırı İlinin Somut Olmayan Kültürel Mirası. Yüksek Lisans Tezi. Kastamonu Üniversitesi, Sosyal Bilimler Enstitüsü, Kastamonu.

Hsiao, K. L., Lu, H. P. and Lan, W. C. (2013). The Influence of The Components of Storytelling Blogs on Readers' Travel Intentions. Internet Research, 23(2), 160-182.

Hsu, S. Y., Dehuang, N. and Woodside, A. G. (2009). Storytelling Research of Consumers' SelfReports of Urban Tourism Experiences in China. Journal of Business Research, 62(12), 1223-1254.

Jahn, M. (2015). Anlatıbilim: Anlatı Teorisi El Kitabı. Çeviren: Bahar Dervişcemaloğlu, İstanbul: Dergah Yayınları.

Kaya B. (2020), Unutulmaz Turizm Deneyiminin Hikâye Anlatıcllğıına Etkisi, Yüksek Lisans Tezi, Batman Üniversitesi, Batman.

Kotler, P., Kartajaya, H. and Setiawan I. (2020). Pazarlama 4.0 Gelenekselden Dijitale Geçiş. İstanbul: Optimist Yayınevi.

Levent, Y. S. (2011). Kültür Mirasına İlişkin Koruma Politikaları ve Uygulamalarında Kamu Yararı İlkesi, Toplum ve Demokrasi, 5(11), 115-132.

Lund, N. F., Cohen, S. A. and Scarles, C. (2018). The Power of Social Media Storytelling in Destination Branding. Journal Of Destination Marketing \& Management, 8, 271-280.

Mathews, R. and Wacker, W. (2009). Senin Hikâyen Ne. Çeviren: Aytül Özer, İstanbul: Mediacat. Mccabe, S. and Foster, C. (2006). The Role and Function of Narrative in Tourist Interaction. Journal of Tourism and Cultural Change, 4(3), 194-215. 
Mossberg, L. (2008). Extraordinary Experiences Through Storytelling. Scandinavian Journal of Hospitality and Tourism, 8(3), 195-210.

Pekyaman, A. (2018). Turist Rehberlerinin Tur Cazibesini Artırmada Yararlanabilecekleri Bir Araç Olarak Efsaneler: Afyonkarahisar Efsaneleri Örneği. Turist Rehberliği Dergisi (Tured), 1(2), 139-152.

Prince, G. (2012). Narratology: The Form and Functioning of Narrative (Vol. 108). Berlin: Walter De Gruyter.

Sütçü, Ö. Y. (2013). Ortak Bir Dünya Deneyimi: Hikâye Anlatıcısı. Felsefe ve Toplumsal Bilimlerde Diyaloglar, 6(2), 76-92.

United Nations Educational, Scientific and Cultural Organization (Unesco). (2014). UNESCO Roadmap for Implementing the Global Action Programme on Education for Sustainable Development, Paris.

United Nations Educational, Scientific and Cultural Organization (Unesco). (1972). Convention Concerning the Protection of The World Cultural and Natural Heritage, Paris.

Uygur, S. M., Demirer, D. ve Hatırnaz, A. G. B. (2017). Turizm Pazarlamasında Alternatif Bir Araç Olarak Hikâyelerin Kullanımı. Akademik Sosyal Araştırmalar Dergisi, 5(42): 34- 42.

Weiler, B. and Walker, K. (2014). Enhancing the Visitor Experience: Reconceptualising the Tour Guide's Communicative Role. Journal of Hospitality and Tourism Management, 21, 90-99.

Wu, Y. C., Lin, S. W. and Wang, Y. H. (2020). Cultural Tourism and Temples: Content Construction and Interactivity Design. Tourism Management, 76, 103972.

Yıldırım, A. ve Şimşek, H. (2008). Sosyal Bilimlerde Nitel Araştırma Yöntemleri (6. Baskı). Ankara: Seçkin Yayıncılık.

Yıldız, T. (2020). Somut Olmayan Kültürel Miras Yönetimi ve Toplumsal Katıllm: Türkiye Örneği. Doktora Tezi, Ankara Hacı Bayram Veli Üniversitesi, Lisansüstü Eğitim Enstitüsü, Ankara.

Zaro, J. J. and Salaberri, S. (1995). Storytelling. Heinemann Publishing, ABD.

Zhong, Y. Y. S., Busser, J., and Baloglu, S. (2017). A Model of Memorable Tourism Experience: The Effects on Satisfaction, Affective Commitment, and Storytelling. Tourism Analysis, 22(2), 201217. 